\title{
Medievalista
}

Online

$30 \mid 2021$

Número 30

The military orders - a foreword

\section{From the East to the West}

The Military Orders - A Foreword

Do Oriente ao Ocidente: As Ordens Militares - Uma Apresentação

\section{Luís Filipe Oliveira and Gregory Leighton}

\section{OpenEdition \\ Journals}

\section{Electronic version}

URL: https://journals.openedition.org/medievalista/4475

DOI: 10.4000/medievalista.4475

ISSN: 1646-740X

\section{Publisher}

Instituto de Estudos Medievais - FCSH-UNL

\section{Electronic reference}

Luís Filipe Oliveira and Gregory Leighton, "From the East to the West", Medievalista [Online], 30 | 2021

Online since 01 July 2021, connection on 24 July 2021. URL: http://journals.openedition.org/

medievalista/4475 ; DOI: https://doi.org/10.4000/medievalista.4475

This text was automatically generated on 24 July 2021.

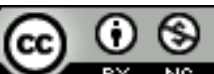

Mediavalista está licenciado com uma Licença Creative Commons - Atribuição-NãoComercial 4.0 Internacional. 
The military orders - a foreword

\section{From the East to the West}

The Military Orders - A Foreword

Do Oriente ao Ocidente: As Ordens Militares - Uma Apresentação

Luís Filipe Oliveira and Gregory Leighton

1 Following an intense, emotional, and extremely challenging year, it is with great pleasure that we introduce this thematic dossier of Medievalista on the history of the military religious orders. The inspiration for this volume comes from previous talks between Luís Filipe Oliveira and Helen Nicholson, in the summer of 2019, when a series of papers were delivered at the International Medieval Congress in Leeds, England, on the history of the military orders. The four sessions there organized, by Helen Nicholson included several researchers and a variety of topics on the origins of the religious-military orders. From their beginnings in the Eastern Mediterranean and in Europe, to their patrons and growth and to their refoundation and recreation in later times, the scope of the four sessions was wide and comprehensive, presenting new data and information on the continued avenues of ongoing research in the field.

2 Having accepted the challenge to publish these texts in Medievalista, Helen Nicholson handed the task to one of her former students, Gregory Leighton, now a post-doctoral researcher at the Nicholas Copernicus University, in Torun, and member of the editorial board of its well-known publication series, the Ordines Militares Colloquia Turonensia Historica. For various reasons, to which the current pandemic was not unrelated, it was not possible to gather all those texts. Of the ten papers presented, only two are included in this dossier, that of Alan Forey and that of Dorothee Heinzelmann and Jürgen Krüger. Therefore, there was a need to reformulate the initial objective and to make new invitations to other researchers. Almost all of these more recent calls for collaboration were met with positive responses, and it has been possible to draw on the assistance of other specialists in the study of military orders. The remaining texts published here, by Karl Borchardt, Joan Fuguet Sans and Carme Plaza Arqué, Philippe Josserand, and Raquel Torres Jiménez, were in response to these calls. In fact, they all fit into the framework of the problems that had been set out for the 
Leeds sessions, bringing new contributions to the history of military orders and their role in the relationship between the Holy Land and the Medieval West.

Oftentimes, when one hears the name 'Templars' or 'Hospitallers', perhaps even 'Teutonic Knights', they are immediately taken to images of the Holy Land, the Temple Mount, and the city of Jerusalem, the places in which the military orders first called 'home'. However, this dossier adds to the ever-increasing body of scholarship on the international history and legacy of the orders throughout Europe, addressing a wide variety of questions and topics and demonstrating the considerable avenues for future research, in addition to providing summaries of ongoing projects. That is surely true with the paper of Alan Forey, a preeminent expert on the history of the military orders on the Iberian Peninsula. In his analysis of the origins of the Templar administration of Provence, Dr. Forey provides a detailed yet accessible survey of a variety of issues to determine precisely when the Order of the Temple began to develop its administrative structure in Iberia. Based in an extensive body of documentary evidence and charters, Forey's paper delves into the importance of linguistics and analysis of the vocabulary of charters to trace the origins of administrations and institutions. A prime example of this can be seen in his examination of key terms in the administrative body of the Templars, namely the offices of prior and claviger (keeper of the keys) to demonstrate that the Temple had created an efficient administrative structure to the north of the Pyrennes by 1150 . Tracing the presence of such terms available in published and unpublished sources to analyse the early provincial history of Templar administrations in the region of Provence, Alan Forey offers us a fascinating and detailed approach that will surely be of interest to those who study the internal administration and functioning of branches of the military orders in the twelfth century.

The role of the military orders closer to 'home' and through the lens of material culture is also addressed in this dossier. Dorothee Heinzelmann and Jürgen Krüger offer a contribution on understanding and reconstructing the Hospitallers' headquarters in Jerusalem, the so-called 'Muristan.' This complex has been the subject of scholarly interest for over two centuries. However, little of it has remained for some time, and so we are forced to delve into the written, archaeological, and photographic evidence as a means to gain further insight into its functions. Prof. Heinzelmann and Prof. Krüger's contribution allows us to do this. The piece provides the most recent summaries of a project to reconstruct this central building of the Hospitaller order in Jerusalem, drawing on a wide variety of materials, including archival photographs and plans drawn during the excavation of the site in early twentieth century. As with all project reports, there still remain some areas for future development, but the contribution will surely draw the interests of historians of the Hospitallers specifically, and specialists in the history of the military orders and material culture as a whole.

The articulation of the Holy Land with the West, in which resided the very institutional originality of the military orders, from the Templars, to the Hospitallers and the Teutonic Knights, is the theme that Philippe Josserand addresses from the Templar province in Portugal. Reacting against a very common prejudice, present even in the most recent works, which sees the Templars in Portugal as an autonomous province, if not as a Portuguese institution, the author emphasizes the regularity and normality of the brothers' contacts with the Orient. Along with other data that is mentioned, he uses an unprinted charter, published in an appendix, about the journey that Lourenço Martins, lieutenant of the provincial master, made to the Holy Land, which was issued 
in Barcelona in April 1282. The charter reveals not only the amount of resources sent to the East - 45 to 50 horses, or mules, with their respective burdens - but also the regularity of these dispatches, with well-established routines. The entire operation was negotiated at a distance, perhaps from Portugal, but it had the intermediation of the commander of Palau-solità, on which the Templar house in Barcelona depended. Given the findings of this article, a significant and urgent revision of the perspectives that ignore, or minimize, the relations of the Portuguese brethren with the Holy Land, their subordination to the master, and to the central structures of the Temple order arises.

6 The remaining papers deal mainly with the establishment and presence of the military orders in the West, in addition to the reinvention of their missions in later times. Joan Fuguet and Carme Plaza's contribution studies how networks of influence and power were built around Templar commanderies in Catalonia, analyzing the trajectory of a lineage of the warrior aristocracy, the Queralt-Timor, a family associated since the late 12th century with the commendary of Barberà, in Tarragona. If the relationship had advantages for both sides, the sponsorship of the members of this family was a decisive factor in consolidating Templar holdings. It also gave rise to other ties, with the admission of some of them, as donatos, to the confraternity of the militia, or even with the profession of some others, although these are usually late professions, made after forming a family and passing its heritage to the next generation. Along with their spiritual motivations, careers in the Order of Temple had an instrumental value for them, serving to strengthen their status and heritage in the region. Among the QueraltTimor parents, such as the Anglesola, the Castellnou or the Rocaberti, the pattern was not very different, although there seems to be a predominance in the recruitment of brethren among the second-born children of these lineages. Their careers seem to be limited to the administration of commendaries and other offices within the Templar province, although Damau de Timor was Turcopolier in Cyprus at the beginning of the 14 th century.

7 The paper presented by Raquel Torres Jiménez provides important data for the study of military orders as religious institutions, especially at the level of parish structures and religious assistance. Based on the 85 visitations made to the Campo de Calatrava, in Castile, between 1491 and 1539, the religiosity of lay women is studied from a male perspective, a theme that has been less explored. In addition to the contrast and conflict between educated religiosity, that of visitors, and the religious practices of rural areas, she documents the familiarity of women with the realities of local liturgical life, such as masses, hourly prayers and divine services. Above all, the paper highlights their devotion to the ornamentation of temples and sacred images, along with their special care for the office of the family deceased. On the other hand, the centrality of the convent of Calatrava in local religious life is also discussed, with the habitual presence of women in conventual spaces, such as the cloister and the dormitory, whether for devotional reasons, or to gain indulgences, or even, to attend the new masses of the convent clerics. Although prohibited by the abbot William II of Morimond in 1468, these practices continued until the beginning of the 16th century, when women were not allowed to stay in the convent at night.

Moving away from the Iberian Peninsula, Karl Borchardt's contribution examines the history of the Hospitaller Order in Central Europe from the fourteenth to the sixteenth centuries. Based around a document issued in 1392, Prof. Borchardt's paper examines the question of 'national' identities in the Middle Ages. Moreover, through this 
document, namely a land dispute between the Hospitallers of Austria and Styria, the paper suggests that it is the tension between the Hospitaller houses in the Middle Ages that can actually be seen as responsible for Austrian independence from Bohemia. Karl Borchardt's paper is a testament to the potential avenues for research into the history of the military orders in Europe during the Later Middle Ages, evidenced in the source edition and English translation that accompanies his paper. A bigger question also emerges in this contribution, too. Given the present-day uses and misuses of the military orders in popular culture, this paper is a thorough examination of the connections to and perceptions of national identities within the military orders in the Middle Ages. As Karl Borchardt states, ethnic and linguistic conflicts were of more importance in the minds of contemporaries, as opposed to any sort of 'proto-national' identity. The contribution thus serves as a rebuttal of the typical abuses of the history of the military orders (in this case, the Hospitallers in Austria) as belonging to any one 'nationality'. A simple, but well advised remark, still useful up to the present day in terms of how scholars approach the history of these institutions.

\section{AUTHORS}

\section{LUÍS FILIPE OLIVEIRA}

Universidade do Algarve, Faculdade de Ciências Humanas e Sociais. Campus de Gambelas, 8005-139 Faro, Portugal. Universidade Nova de Lisboa, Faculdade de Ciências Sociais e Humanas, Instituto de Estudos Medievais, 1070-312 Lisboa, Portugal. lfolivei@ualg.pt .https://orcid.org/ 0000-0001-7861-9311

\section{GREGORY LEIGHTON}

Nicholas Copernicus University, Jurija Gagarina 11, 87-100 Toruń, Polónia.

gregjleighton@gmail.com. https://orcid.org/0000-0002-4203-2313 